\title{
Analysis of the fraction of delivered oxygen by noninvasive ventilation devices working as invasive ventilators in pandemic times
}

Gerardo Tusman ( $\sim$ gtusman@hotmail.com )

Hospital Privado de Comunidad

Emiliano Gogniat

Pneumonology Committee of Argentinian Critical Care Society

Gustavo Plotnikow

Sanatorio Anchorena Buenos Aires

Marcelo Campos

Sanatorio Finocchietto, Buenos Aires,

\section{Short Report}

Keywords: COVID-19, mechanical ventilation, noninvasive ventilation, ventilators, FD02, oxygen

Posted Date: July 21st, 2020

DOI: https://doi.org/10.21203/rs.3.rs-45743/v1

License: (a) (i) This work is licensed under a Creative Commons Attribution 4.0 International License. Read Full License 


\section{Abstract}

Purpose: In the context of the COVID-19 pandemic, mandatory ventilation with noninvasive ventilation (NIV) devices is a valid option when intensive care/anesthesia ventilators are unavailable. The fraction of delivered oxygen $\left(\mathrm{FDO}_{2}\right)$ by NIV devices in intubated patients is unknown.

Method: We simulated intubated patients with normal and sick lungs. NIV was used in pressure control mode with protective lung ventilatory settings. $\mathrm{O}_{2}$ flow was added into the NIV circuit in incremental steps of $1 \mathrm{~L} /$ min (from 1 to $15 \mathrm{~L}$ ). The $\mathrm{FDO}_{2}$ in breathing gases was measured by a paramagnetic $\mathrm{O}_{2}$ sensor placed behind the endotracheal tube. Three NIV circuit options were analyzed: 1) leak at HME filter close to the patient, 2) anesthesia Bain circuit with leak distal to the patient, and 3) leak throughout a nonrebreathing valve near the patient.

Results: $\mathrm{FDO}_{2}$ increased proportional to the supplemental $\mathrm{O}_{2}$ flow in all NIV options and in both kinds of patients. The range of $\mathrm{FDO}_{2}$ came from 0.25 to 0.98 in both, healthy and sick lungs. At $5 \mathrm{~L} / \mathrm{min}, \mathrm{FDO}_{2}$ was $0.53 \pm 0.04$ and $0.47 \pm 0.02$ in option 1 and $0.53 \pm 0.04$ and $0.47 \pm 0.02$ in option 2 for healthy and sick lungs, respectively. In option $3,5 \mathrm{~L} / \mathrm{min}$ of $\mathrm{O}_{2}$ reached $0.84 \pm 0.08$ in healthy and $0.74 \pm 0.09$ in sick lungs.

Conclusions: In all setups, $\mathrm{FDO}_{2}$ was proportional to the administered $\mathrm{O}_{2}$ flow and it covered the range of $\mathrm{FDO}_{2}$ values commonly observed in ventilated patients.

\section{Introduction}

Respiratory failure induced by the SARS-CoV-2 virus is a key feature in most patients with COVID-19 [1,2]. The high contagiousness of the virus (Ro $=2.2-3.5)$ [3] increases the number of people infected exponentially, explaining why health systems collapsed all over the world. The problem is particularly severe in intensive care units (ICU) where beds and ventilators could be fully occupied with COVID-19 cases that require invasive ventilation longer than usual. In such critical scenario even anesthesia workstations have been utilized to ventilate COVID-19 patients, limiting the number of this crucial equipment in the operating rooms.

The use of noninvasive ventilation (NIV) devices in-lieu of invasive ICU ventilators has been recently suggested in the context of the COVID-19 pandemic [4]. Noninvasive ventilation was proposed as a second line strategy when ventilators and/or anesthesia machines are not available and patients need ventilatory support for acute respiratory failure or for general anesthesia. This is clearly an emergency situation for the pandemic that is not appropriated for normal circumstances. The FDA approved NIV devices to be used in intubated patients at the time of writing of this manuscript (https://www.fda.gov/medical-devices/letters-health-care-providers/ventilator-supply mitigationstrategies-letter-health-care-providers. Accessed April 20, 2020). 
There are many comparative advantages and disadvantages between NIV devices when compared to ICU and anesthesia workstations [5]. Perhaps the main limitation of NIV is the difficulty to get precise fraction of delivered oxygen $\left(\mathrm{FDO}_{2}\right)$, therefore, specific $\mathrm{O}_{2}$ flow/ $\mathrm{FDO}_{2}$ tables are needed to adjust the oxygen therapy. Such information was described in two studies that simulated NIV in spontaneous breathing patients using masks $[6,7]$. However, these data are only approximations because the $\mathrm{FDO}_{2}$ is easily modify by unintended leaks around poor-fitting masks and the patient's minute ventilation. In intubated patients with cuffed endotracheal tubes, NIV devices work with an intended air-leak in the ventilatory circuit but without any additional "unintended" leaks like with facial interfaces. Thus, for most of the NIV devices, the $\mathrm{FDO}_{2}$ delivered to patients undergoing mandatory ventilation is unknown.

The main objective of this brief report was to analyze the $\mathrm{FDO}_{2}$ supplied by NIV devices working as invasive ventilators. The analysis was performed in a bench study at this first step, simulating patients with healthy and sick lungs using different NIV circuit configurations at different supplemental $\mathrm{O}_{2}$ flows. End-point of the analysis was the measurement of $\mathrm{FDO}_{2}$ at the airways opening. The primary outcome was to describe the $\mathrm{FDO}_{2}$ obtained at different additional $\mathrm{O}_{2}$ flow for different NIV circuit dispositions.

The IRB of the Hospital Privado de Comunidad, Mar del Plata, Argentina approved the use of clinical data recorded in three anesthetized patients to illustrate the results of simulations (waiver for patients' written informed consent).

\section{Methods}

\section{NIV devices working as an invasive ventilator}

To operate as an invasive ICU ventilator the NIV device must have the following features:

- To allow pressure control and/or S/T modes.

- The NIV device must reach an inspiratory positive airway pressure (IPAP) $\geq 30 \mathrm{cmH}_{2} \mathrm{O}$ and an expiratory positive airway pressure (EPAP) $\geq 10 \mathrm{cmH}_{2}$

- An obligated gas leak port to washout $\mathrm{CO}_{2}$ from the single limb NIV circuit.

- An external $\mathrm{O}_{2}$ source supply. We have administered $\mathrm{O}_{2}$ through a port placed between the singlelimb circuit and the NIV device.

- A heat and moisture exchange (HME) antibacterial/antiviral filter must be placed between the endotracheal tube (ETT) and the NIV circuit. The HME prevents SARS-CoV-2 virus dispersion and keeps humidity of inhaled gas.

Three NIV circuit configurations were proposed to implement ventilation in intubated patients (Figure 1) [4]. These are circuit configurations described for such altered standard of care that must be only used in the context of COVID-19 pandemic. The first option is the standard circuit configuration that has a leak at the HME filter, nearest to the patient. The second one is a modified Bain system ideated to perform 
general anesthesia, which has the advantage to keep heat and humidity in the breathing gases [8]. The circuit has double coaxial tubes one inside the other. The outer tube is connected to the NIV device and delivers inspired gases to the patient while the inner tube transports expired gases to the ambient (leak closer to the NIV equipment). The third option has a non-rebreathing valve like Ruben or Duckbill (similar to those found in $A m b u \circledast$ resuscitation bags) [9], which delivers gases to the patient and then eliminates gases to the ambient throughout a PEEP valve. This atypical circuit option has the theoretical advantage to deliver more $\mathrm{O}_{2}$ and to decrease $\mathrm{CO}_{2}$ re-breathing.

\section{Simulations}

The analysis was done in the Simulation Center of the Buenos Aires Association of Anesthesia, Analgesia and Reanimation. Data was collected by the ASL 5000 Breathing Simulator (IngMar Medical, Pittsburgh, USA), which was connected to the NIV device (Stellar 150, ResMed Inc., Sydney, Australia) by a cuffed $\mathrm{n}^{\circ}$ 8 endotracheal tube. This device can be used for noninvasive and invasive ventilation according to manufacturer's specifications. Respiratory mechanics and $\mathrm{CO}_{2}-\mathrm{O}_{2}$ signals were obtained with sensors placed at the airways opening (S5 device, GE Healthcare/Datex-Ohmeda, Helsinki, Finland). The $\mathrm{O}_{2}$ was measured by paramagnetic sensor with an accuracy $<2 \%$ of reading, rise time $<260$ milliseconds and measurement range between 0 to $100 \%[9,10]$. Sensors were calibrated before protocol as described by the manufacturer. Data was recorded by the software Datex Collect (GE Healthcare/Datex-Ohmeda, Helsinki, Finland) in a laptop and was analyzed off-line.

We simulated two kinds of patients based on lung mechanics. One patient with healthy lungs, with a respiratory compliance of $50 \mathrm{~mL} / \mathrm{cmH}_{2} \mathrm{O}$ and airways resistance of $5 \mathrm{cmH}_{2} \mathrm{O} / \mathrm{L} / \mathrm{s}$, while ventilated with an inspiratory positive airways pressure (IPAP) of $22 \mathrm{cmH}_{2} \mathrm{O}$, an expiratory positive airways pressure (EPAP) of $8 \mathrm{cmH}_{2} \mathrm{O}$, a respiratory rate of $15 \mathrm{bpm}$ and an inspiratory time of 0.9 seconds. The other simulated patient with compromised lungs, a respiratory compliance of $30 \mathrm{~mL} / \mathrm{cmH}_{2} \mathrm{O}$, an airways resistance of $12 \mathrm{cmH}_{2} \mathrm{O} / \mathrm{L} / \mathrm{s}$ while ventilated with an IPAP of $28 \mathrm{cmH}_{2} \mathrm{O}$, an EPAP of $14 \mathrm{cmH}_{2} \mathrm{O}$, a respiratory rate of $25 \mathrm{bpm}$ and an inspiratory time of 0.9 seconds.

\section{Protocol}

In each simulated patient and for all three NIV circuit configurations (Figure 1) we have tested with an increased $\mathrm{O}_{2}$ supply, from 1 to $10 \mathrm{~L} / \mathrm{min}$ in incremental steps of $1 \mathrm{~L} / \mathrm{min}$, to a final maximum flow of 15 $\mathrm{L} / \mathrm{min}$. Each step of $\mathrm{O}_{2}$ flow was maintained by 3 minutes separated by a washout period of another 3 minutes to reach a stable condition. Simulation was repeated three times in different days by different operators. Data is presented as mean \pm SD.

\section{Data of anesthetized patients}

Preliminary data recorded in three American Society of Anesthesiologists Classification 1 patients undergoing laparoscopic procedures was used to illustrate the results of simulations. In these patients, 
the ventilatory settings and the recording system (S5 device with Datex Collect software both, GE Healthcare/Datex-Ohmeda, Helsinki, Finland) were similar than the simulations for healthy lungs.

\section{Results}

\section{Simulations}

Main results of simulations are described in table $1 . \mathrm{FDO}_{2}$ increased proportionally to the external $\mathrm{O}_{2}$ flow in all setups and for both, healthy and compromised lungs. Option 1 and 2 presented similar $\mathrm{FDO}_{2}$ with increment in supplementary $\mathrm{O}_{2}$ flow. The highest $\mathrm{FDO}_{2}$ was observed with the non-rebreathing valve that reached $>0.90$ with an $\mathrm{O}_{2}$ flow $\geq 10 \mathrm{~L} / \mathrm{min}$ in both kinds of lungs. The simulation in the patient with compromised lungs showed slightly less $\mathrm{FDO}_{2}$ than the healthy one in all NIV circuit dispositions.

Table 1: Fraction of delivered 02 reached at different 02 flow for the three NIV circuit dispositions in healthy and sick lungs. 


\begin{tabular}{|c|c|c|c|c|c|c|}
\hline \multirow[b]{2}{*}{$\begin{array}{c}\mathrm{O}_{2} \\
\text { Flow } \\
(\mathrm{L} / \mathrm{min})\end{array}$} & \multicolumn{3}{|c|}{ Healthy lungs } & \multicolumn{3}{|c|}{ Sick lungs } \\
\hline & $\begin{array}{c}\text { Option } 1 \\
\text { (leak at HME) }\end{array}$ & $\begin{array}{c}\text { Option } 2 \\
\text { (Bain) }\end{array}$ & $\begin{array}{l}\text { Option } 3 \\
\text { (N-R valve) }\end{array}$ & $\begin{array}{c}\text { Option } 1 \\
\text { (leak at HME) }\end{array}$ & $\begin{array}{l}\text { Option } 2 \\
\text { (Bain) }\end{array}$ & $\begin{array}{l}\text { Option } 3 \\
\text { (N-R valve) }\end{array}$ \\
\hline 1 & $\begin{array}{l}0.27 \pm \\
0.01\end{array}$ & $\begin{array}{l}0.26 \pm \\
0.01 \\
\end{array}$ & $0.35 \pm 0.04$ & $0.26 \pm 0.01$ & $0.25 \pm 0.01$ & $0.32 \pm 0.02$ \\
\hline 2 & $0.31 \pm 0.01$ & $\begin{array}{c}0.31 \pm \\
0.02\end{array}$ & $0.52 \pm 0.12$ & $0.31 \pm 0.01$ & $0.29 \pm 0.01$ & $0.42 \pm 0.04$ \\
\hline 3 & $0.34 \pm 0.01$ & $\begin{array}{c}0.36 \pm \\
0.02\end{array}$ & $0.69 \pm 0.08$ & $0.35 \pm 0.01$ & $0.32 \pm 0.01$ & $0.54 \pm 0.08$ \\
\hline 4 & $0.41 \pm 0.02$ & $\begin{array}{c}0.45 \pm \\
0.03\end{array}$ & $0.78 \pm 0.13$ & $0.40 \pm 0.01$ & $0.37 \pm 0.02$ & $0.64 \pm 0.10$ \\
\hline 5 & $0.53 \pm 0.04$ & $\begin{array}{c}0.49 \pm \\
0.04\end{array}$ & $0.84 \pm 0.08$ & $0.47 \pm 0.02$ & $0.41 \pm 0.02$ & $0.74 \pm 0.09$ \\
\hline 6 & $0.58 \pm 0.08$ & $\begin{array}{c}0.54 \pm \\
0.06\end{array}$ & $0.89 \pm 0.08$ & $0.51 \pm 0.01$ & $0.45 \pm 0.03$ & $0.80 \pm 0.10$ \\
\hline 7 & $0.63 \pm 0.09$ & $\begin{array}{c}0.59 \pm \\
0.06\end{array}$ & $0.91 \pm 0.06$ & $0.55 \pm 0.01$ & $0.49 \pm 0.03$ & $0.89 \pm 0.05$ \\
\hline 8 & $0.70 \pm 0.10$ & $\begin{array}{c}0.63 \pm \\
0.08\end{array}$ & $0.93 \pm 0.05$ & $0.61 \pm 0.03$ & $0.54 \pm 0.04$ & $0.93 \pm 0.04$ \\
\hline 9 & $0.75 \pm 0.12$ & $\begin{array}{c}0.67 \pm \\
0.09\end{array}$ & $0.94 \pm 0.05$ & $0.67 \pm 0.05$ & $0.57 \pm 0.05$ & $0.95 \pm 0.03$ \\
\hline 10 & $0.81 \pm 0.14$ & $\begin{array}{c}0.74 \pm \\
0.09\end{array}$ & $0.95 \pm 0.03$ & $0.73 \pm 0.05$ & $0.61 \pm 0.04$ & $0.97 \pm 0.01$ \\
\hline 15 & $0.88 \pm 0.09$ & $\begin{array}{c}0.85 \pm \\
0.08\end{array}$ & $0.97 \pm 0.02$ & $0.83 \pm 0.05$ & $0.77 \pm 0.08$ & $0.98 \pm 0.01$ \\
\hline
\end{tabular}

$\mathrm{HME}=$ heat and moisture exchange antibacterial/antiviral filter. Bain = anesthesia Bain circuit. N-R = nonrebreathing valve.

\section{Data of anesthetized patients}

We included data of 3 healthy adult patients undergoing laparoscopic surgery with general anesthesia ( 1 male/ 2 females, age $45 \pm 15$ years old, weight $69 \pm 12 \mathrm{~kg}$ and height $165 \pm 17 \mathrm{~cm})$. Table 2 showed the $\mathrm{FiO}_{2}$ reached at 5,10 and $15 \mathrm{~L} / \mathrm{min}$ with the three types of NIV circuits studied. Data was quite similar to the values obtained during simulations of patients with healthy lungs. The highest $\mathrm{FDO}_{2}$ was reached by the non-rebreathing valve at all supplemental $\mathrm{O}_{2}$ flows just like with the simulations.

Table 2: Fraction of delivered $\mathrm{O}_{2}$ at different supplemental $\mathrm{O}_{2}$ flow in real anesthetized patients. 


\begin{tabular}{|c|c|c|c|}
\hline \multirow{2}{*}{$\begin{array}{c}\mathrm{O}_{2} \\
\text { Flow } \\
(\mathrm{L} / \mathrm{min})\end{array}$} & $\begin{array}{c}\text { Option 1 } \\
\text { (leak at HME) }\end{array}$ & $\begin{array}{c}\text { Option 2 } \\
\text { (Bain) }\end{array}$ & $\begin{array}{c}\text { Option 3 } \\
\text { (N-R valve) }\end{array}$ \\
\cline { 2 - 4 } & $0.49 \pm 0.04$ & $0.46 \pm 0.06$ & $0.80 \pm 0.07$ \\
\hline 5 & $0.75 \pm 0.05$ & $0.72 \pm 0.08$ & $0.89 \pm 0.02$ \\
\hline 10 & $0.84 \pm 0.02$ & $0.80 \pm 0.02$ & $0.91 \pm 0.01$ \\
\hline 15 & & & \\
\hline
\end{tabular}

$\mathrm{HME}=$ heat and moisture exchange antibacterial/antiviral filter. Bain = anesthesia Bain circuit. $\mathrm{N}-\mathrm{R}=$ nonrebreathing valve.

Figure 2 showed the temporal series of the main output variables (flow, pressure, capnography and oxigraphy) in one patient using the setup described in option 2. The patient was undergoing a laparoscopic surgery with an IPAP of $21 \mathrm{~cm} \mathrm{H}_{2} \mathrm{O}$ and EPAP of $10 \mathrm{cmH}_{2} \mathrm{O}$. Airways pressure was maintained at the set pressures without any $\mathrm{CO}_{2}$ rebreathing. The lack of $\mathrm{CO}_{2}$ rebreathing was confirmed by capnography because the $\mathrm{CO}_{2}$ signal reached zero at the end of expiration.

Figure 3 depicted an increase in $\mathrm{FDO}_{2}$ caused by incremental $\mathrm{O}_{2}$ flow in other patient using the option 1 with a fixed ventilatory pattern. The upper figure shows the kinetics of $\mathrm{O}_{2}$ during the increase in $\mathrm{O}_{2}$ flow from 0 to $5 \mathrm{~L} / \mathrm{min}$. Both, the fraction of $\mathrm{O}_{2}$ at end-inspiration and end-expiration reached a new equilibrium in a few breaths.

Figure 4 shows the increase in $\mathrm{FDO}_{2}$ for each NIV circuit options analyzed when $\mathrm{O}_{2}$ flow was increased in steps of $5 \mathrm{~L} / \mathrm{min}$. Data was collected in the same patient with the same ventilatory settings than simulation of healthy lungs. Results are similar to the ones observed during the simulations; where the setup using the non-rebreathing valve showed the highest $\mathrm{FDO}_{2}$ values when compared to options 1 and 2.

\section{Discussion}

Our results describe the range of $\mathrm{FDO}_{2}$ reached by three different NIV circuit configurations in simulated intubated patients with healthy and compromised lungs. The $\mathrm{FDO}_{2}$ was related to the administered $\mathrm{O}_{2}$ flow in all setups and reached the highest value with the use of a non-rebreathing valve. This data gives information about how much $\mathrm{O}_{2}$ can be delivered by NIV devices when using for mandatory invasive ventilation. 
The values of $\mathrm{FDO}_{2}$ obtained by simulations (Table 1) corresponded to the data observed in anesthetized patients at similar ventilatory settings and supplemental $\mathrm{O}_{2}$ flow (Table 2). However, the $\mathrm{FDO}_{2}$ values we found are much higher than those simulations reported during spontaneous breathing using facial interfaces [6,7]. These differences are probably due to the unintended leaks commonly observed around masks that do not happen in patients with sealed circuit and cuffed endotracheal tube. The leaks throughout the mask are compensated by the NIV device increasing flow to maintain the set pressures. This effect dilutes the $\mathrm{O}_{2}$ and changes $\mathrm{FDO}_{2}$ within the NIV circuit because the supplemental $\mathrm{O}_{2}$ flow keeps constant.

The lower $\mathrm{FDO}_{2}$ observed in sick lungs compared with healthy lungs could be explained by the high IPAP and EPAP used in the former. These results fit with the description of Schwartz et al. [6] and Thys et al. [7] using bench models and volunteers. The authors found that selecting high pressures increase not only the flow through the leak but also the NIV flow to compensate such leaks. The final result is the dilution of $\mathrm{O}_{2}$ within the NIV circuit and the consequent reduction in the $\mathrm{FDO}_{2}$.

The NIV circuit with the unidirectional, non-rebreathing valve showed the highest $\mathrm{FDO}_{2}$. This is because such valve allows unidirectional flow during the respiratory cycle phases. The "leak" is closed during inspiration and fresh gases reach the patient. Then, the expired gases rich in $\mathrm{CO}_{2}$ tend to scape outside through the valve during expiration. The combination of these effects is a lower dilution of $\mathrm{O}_{2}$ within the single circuit of NIV. Thus, this NIV circuit disposition must be used in those cases when high $\mathrm{FDO}_{2}$ is necessary like in patients with severe respiratory failure or during one-lung anesthesia. The main disadvantage of this NIV circuit disposition is the additional expiratory work imposed by the nonrebreathing and PEEP valves. This is a problem during assisted ventilation ( $\mathrm{S} / \mathrm{T}$ mode) that can be easily resolved by changing to circuit options 1 or 2 at the very moment when a patient is ready to re-start spontaneous breathing.

\section{Limitations}

We have simulated changes in $\mathrm{FDO}_{2}$ caused by increments in the $\mathrm{O}_{2}$ flow supply, keeping constant all the other ventilatory variables. Such variables like IPAP/EPAP values, placement of circuit leak, place of supplemental $\mathrm{O}_{2}$ administration, respiratory rate, inspiratory time, etc. could affect the $\mathrm{FDO}_{2}$ in NIV devices used as invasive ventilators. Due to the urgency to get alternative ventilatory options during the COVID-19 pandemic, we believe that the information we generated, while limited to changes in additional $\mathrm{O}_{2}$ flow, it may prove useful to intensive care health-providers and anesthesiologists at this stage. Further studies should be done to get more information on the topic.

\section{Conclusion}

This study gives clinical information to manage $\mathrm{FDO}_{2}$ when NIV devices are used for mandatory ventilation in intubated patients. The range of $\mathrm{FDO}_{2}$ reached by all NIV circuit options covers the range of 
values used in our ventilated patients with intensive care/anesthesia ventilators. Our results should not be transferred to patients in spontaneous assisted ventilation and surely new studies should be done to cover this issue.

\section{Declarations}

\section{Informed Consent:}

The IRB of the Hospital Privado de Comunidad, Mar del Plata, Argentina approved the use of clinical data recorded in three anesthetized patients to illustrate the results of simulations (waiver for patients' written informed consent).

Fundings: The study was supported by local resources of the Simulation Center of Buenos Aires Association of Anesthesia, Analgesia y Reanimation, Buenos Aires, Argentina.

\section{Conflict of Interest Statement: No potential conflicts of interest exist.}

\section{Availability of data: on request.}

Authors' contributions: Gerardo Tusman: Literature search, data collection, study design, manuscript preparation, review manuscript. Emiliano Gogniat: Literature search, data collection, review manuscript. Gustavo A. Plotnikow: Literature search, data collection, review manuscript. Marcelo D. Campos: Literature search, data collection, study design, manuscript preparation, review manuscript.

Sources of Funding: None.

Clinical trial number: Not applicable.

\section{References}

1. Wang D, Hu B, Hu C, et al. (2020) Clinical characteristics of 138 hospitalized patients with 2019 novel coronavirus-infected pneumonia in Wuhan, China. JAMA DOI:10.1001/jama.2020.1585

2. Zhou F, Yu T, Du R, Fan G, Liu Y, Liu Z, et al. (2020) Clinical course and risk factors for mortality of adult inpatients with COVID-19 in Wuhan, China: a retrospective cohort study. The Lancet https://doi.org/10.1016/S0140-6736(20)30566-3

3. Lai CC, Shih TP, Ko WC, Tang HJ, Hsueh PR. (2020) Severe acute respiratory syndrome coronavirus 2 (SARS-CoV-2) and coronavirus disease-2019 (COVID-19): The epidemic and the challenges. Int $J$ Antimicrobial Agents. https://doi.org/1016/j.ijantimicag.2020.105924

4. Tusman G, Campos MD, Gogniat E. (2020) COVID-19: How to transform a noninvasive ventilation device in a critical care ventilator. Rev Esp Anest Reanim https://doi.org/1016/j.redar.2020.05.002 
5. Scala R, Naldi M. (2008) Ventilators for noninvasive ventilation to treat acute respiratory failure. Respir Care 53:1054-1080

6. Schwartz AR, Kacmarek RM, Hess DR. (2004) Factors affecting oxygen delivery with Bi-Level positive airways pressure. Respir Care 49:270-275

7. Thys F, Liistro G, Dozin O, Rodenstein DO. (2002) Determinants of FIO2 with oxygen supplementation during noninvasive two-level positive pressure ventilation. Eur Respir J 19:653-657

8. Bain JA, Spoerel WE. (1972) A streamlined anaesthetic system. Can Anaesth Soc J 19:426-435

9. Sivco CS, Cherian VT. (2018) What every anesthesiologist should know about the manual resuscitation bag. A\&A Practice 11:288-291

10. Meriläinen PT. (1988) A differential paramagnetic 02-sensor. Int J Clin Monit Comput 5:187-195

11. Linko K, Paloheimo M. (1988) Monitoring of the inspired and end-tidal oxygen, carbon dioxide, and nitrous oxide concentrations: clinical applications during anesthesia and recovery. J Clin Monit 5:149-156

\section{Figures}



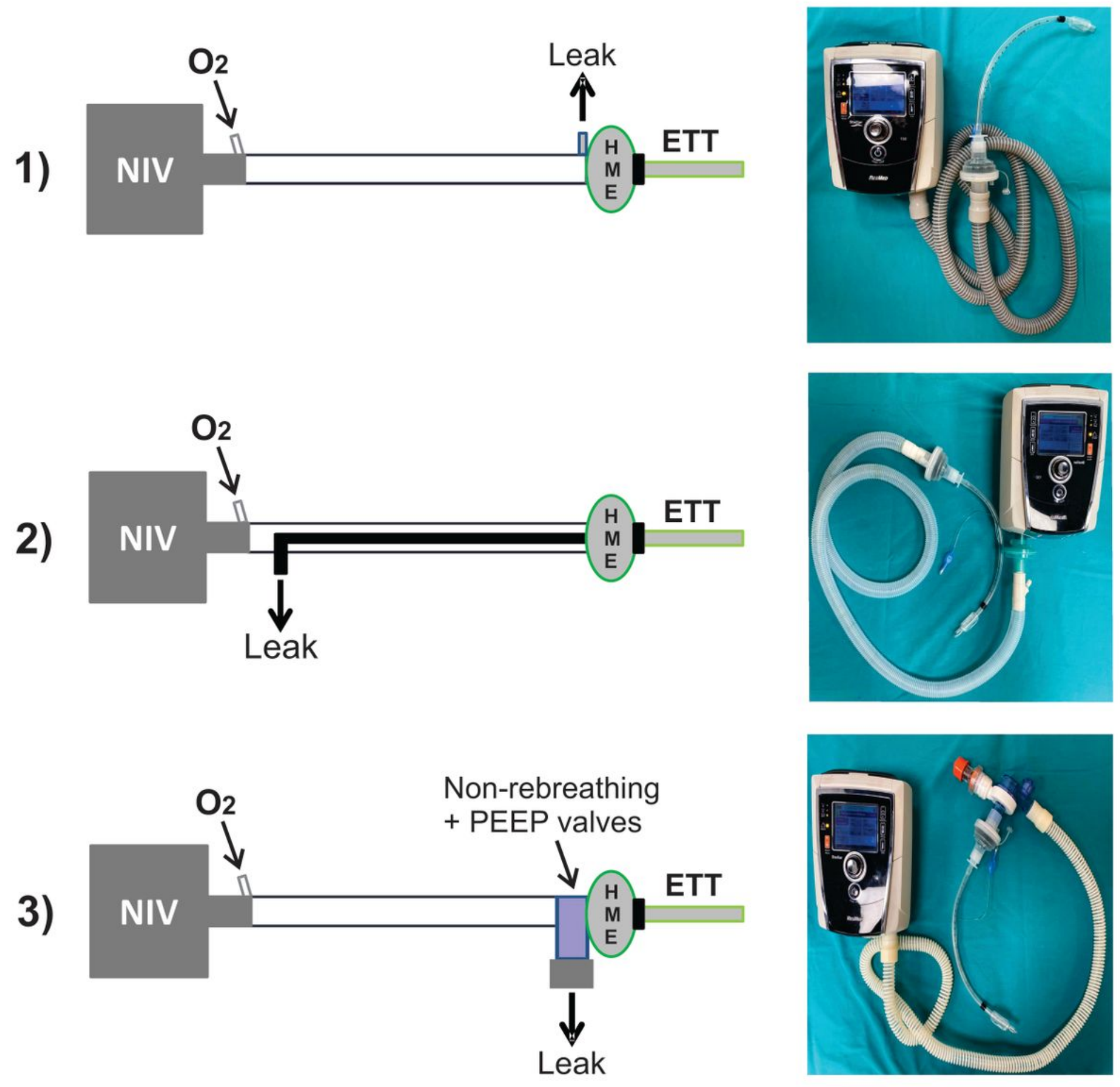

\section{Figure 1}

Three NIV circuit configurations to perform mandatory ventilation were studied. In option 1 the leak is placed distal to the NIV device, at the heat and moisture exchange (HME) filter. The second option is a modified anesthesia Bain coaxial circuit, where inspired gases go through the external limb and the expired gases are eliminated by the internal coaxial tube. The third option has a non-rebreathing unidirectional valve. Such valve is placed behind the HME where all the exhaust gases come outside the circuit through a PEEP valve. In all options, supplemental oxygen (02) is administered between the NIV device and its single circuit. 

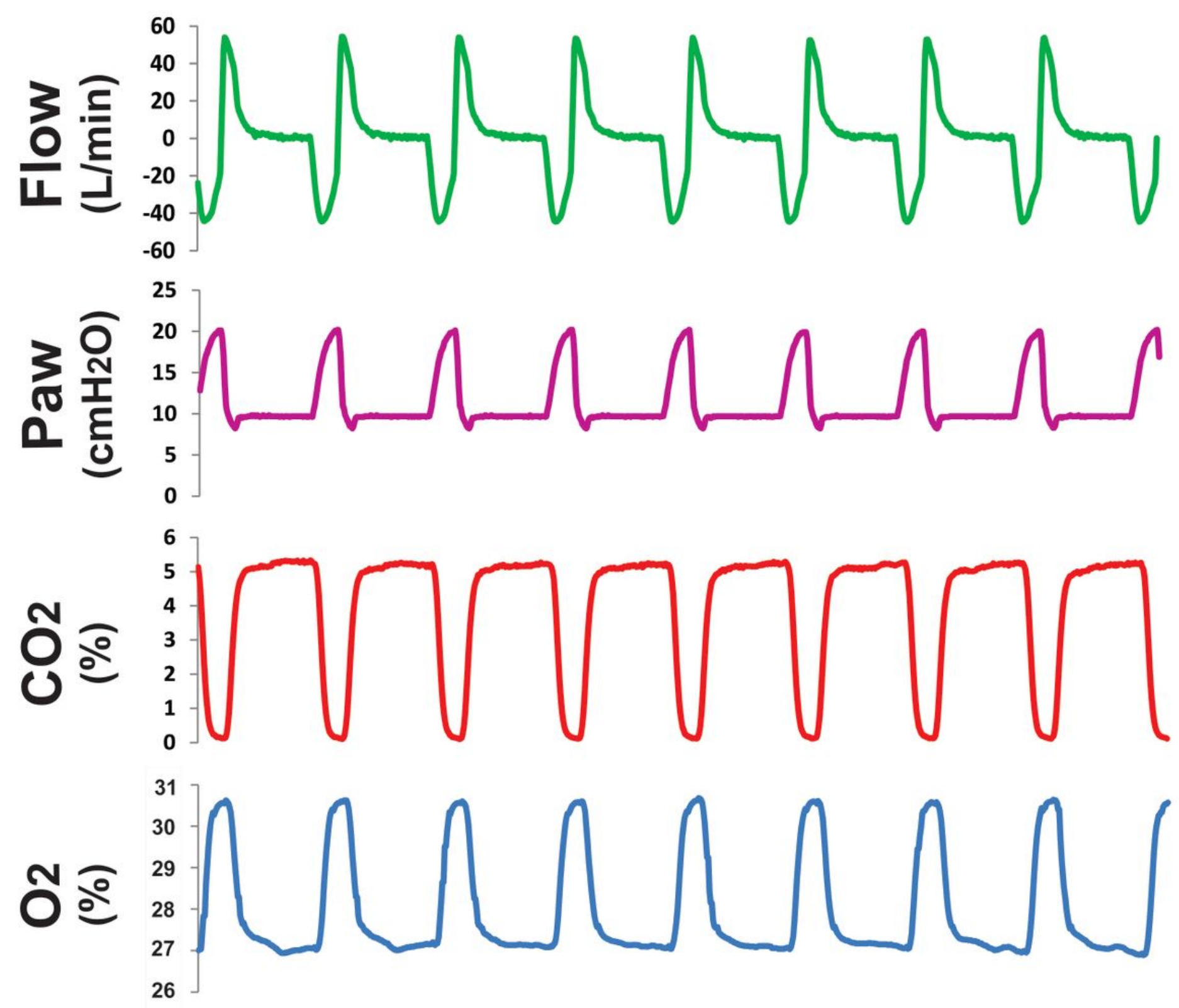

Figure 2

Flow, pressure, capnography (CO2) and oxygraphy (02) temporal series were collected in a patient undergoing general anesthesia using a Bain circuit (Option 2). Note that oxygraphy is a mirror image of capnography. 


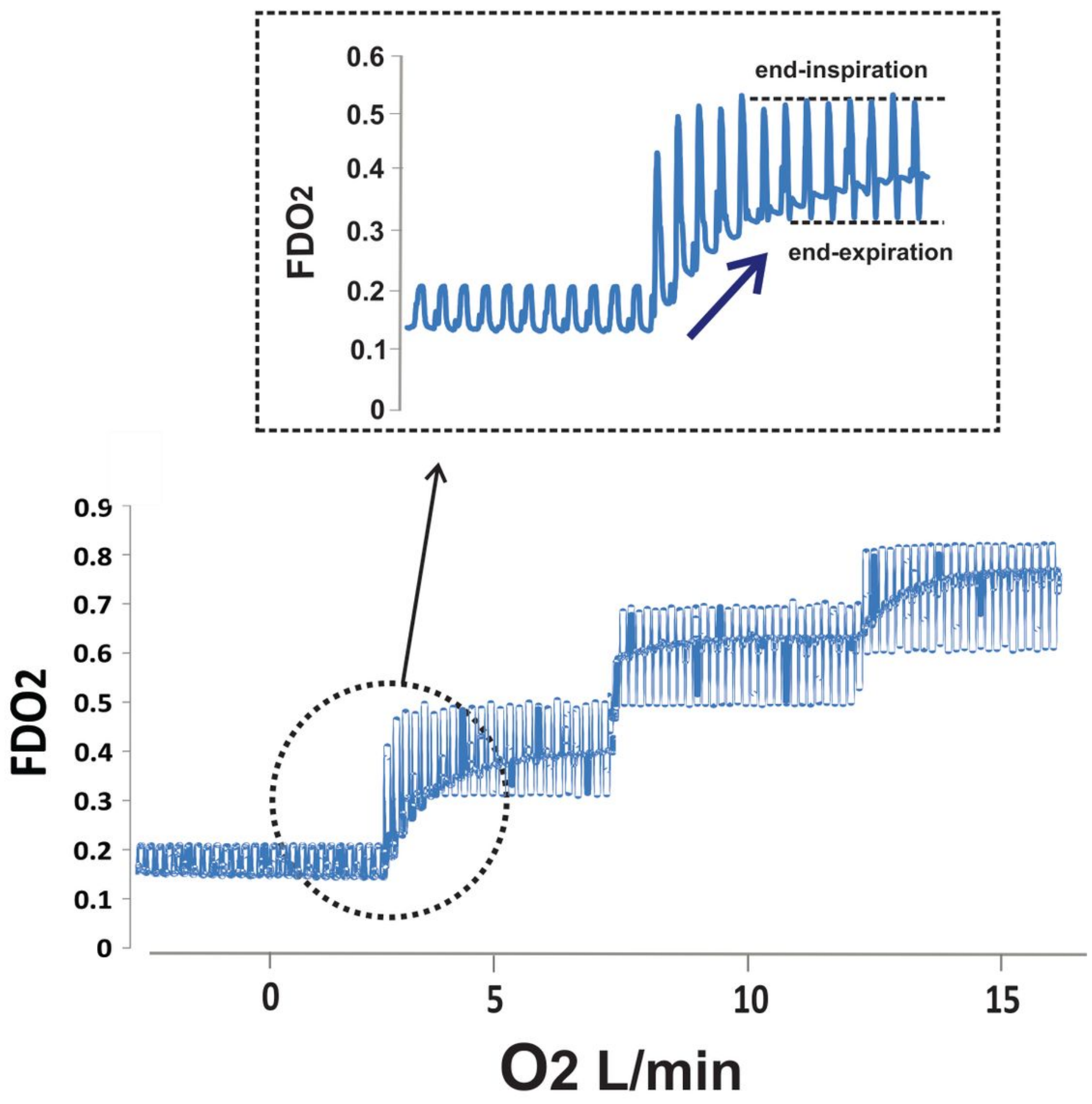

Figure 3

Supplemental 02 flow was changed in one anesthetized patient during fixed ventilation using option 1 (leak at HME filter). Ventilatory settings was similar to the one simulated in a healthy patient. The figure on the top depicts how fast the fraction of $\mathrm{O} 2$ at end-inspiration and end-expiration reached stable values after the addition of $5 \mathrm{~L} / \mathrm{min}$ of 02 . 


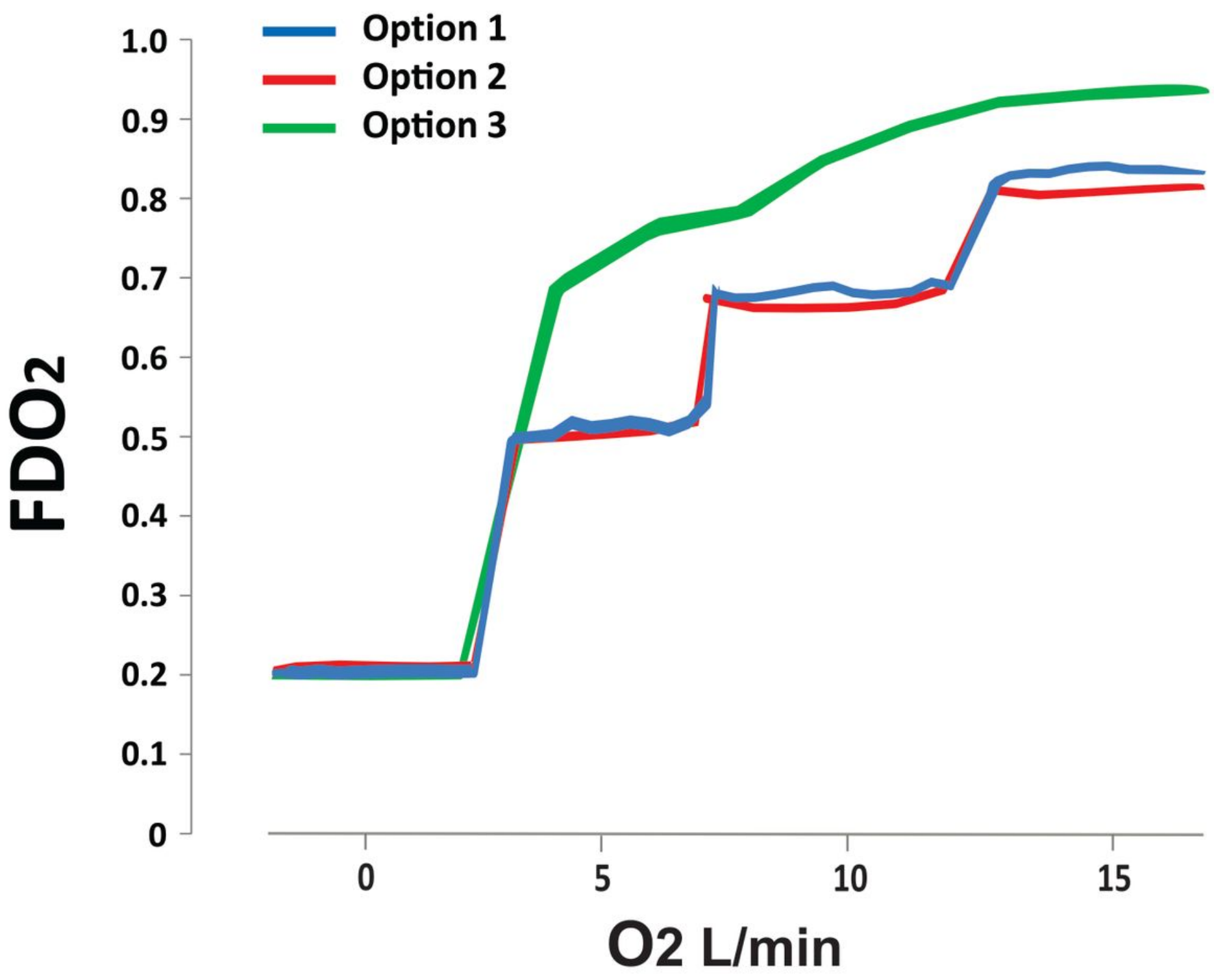

Figure 4

Each NIV circuit analyzed belongs to an anesthetized patient ventilated with the same setting than the simulation performed in healthy lungs. Supplemental 02 was increased in three steps. Blue $=$ option 1 , distal leak at HME. Red = option 2, anesthesia Bain circuit. Green = option 3, non-rebreathing valve. 